Coleman; on sanitary arrangements and house-building in towns, by Mr. James Sellars; on Egyptian obelisks, by Mr. T. L. Patterson; on producing cast iron or ingot iron from crude or pig iron, by Mr. W. Gorman; on the heat-restoring gas furnace and heating by radiation, by Mr. W. Gorman; on uncertified deaths, by Dr. Glaister; on the spread of disease by manure poisoning, by Dr. E. Duncan ; and on the form of the human skull, by Prof. Cleland. The two maps, prepared by Mr. Ravenstein, and presented to the Society by Mr. James Stevenson, are specially valuable as showing the most recent results of African travel.

During the session M. Louis Pasteur, Prof. $\Lambda$ sa Gray, and Rev. John Kerr, LL.D., were elected honorary members, and Mr. George Anderson, lately M.P. for Glasgow, and now Master of the Mint, Melbourne, was elected a corresponding member The Graham medal was awarded to Mr. E. C. C. Stanford for his researches on algin. The Society at present has I8 honorary, II corresponding, and 69I ordinary members, and in addition to the ordinary meetings, there are sections for architecture, chemistry, biology, sanitation and social economy, and geography and ethnology.

\section{AN EARTHQUAKE INVENTION}

$W^{E}$ have been requested to publish the following correspondence :-

Royal Observatory, Edinburgh, Fune 5, 1885

My Dear Mr. David Stevenson,-At p. 248 of the new British Association volume for 1884 there is a section on "Experiments on a Building to Resist Earthquake Motion," which reads amazingly like your paper of twenty years ago; but yet it is not that, for your name does not enter, and they have in a way got round the letter of your invention by employing, in place of your bronze balls in shallow bronze basins, cast iron balls and cast-iron plates, "with saucer-like edges" for the lower basins; and for the upper basins, "cast iron plates slightly concave, but otherwise similar to those below."

Against such men would any patent be safe? though you may not have taken out any patent for your philanthropic invention for saving life in earthquake-persecuted countries; but the whole section is the most indubitable approval of your methods and principles that could well have been proposed by any one. Certainly it transcends anything that could have ever entered the mind of Yours ever very sincerely,

\section{Prazzi Smyth}

Edinburgh, Fune II, 1885

DEAR SIR,--Very many thanks for your letter to my father pointing out the report of the British Association on earthquakes for 1884 , which I had not seen. My father, from the state of his health, is unfortunately unable to take the matter up himself, but if you will permit me to publish your very interesting and well-put letter in NATURE it will give the honour of the invention to whom the honour is due. My father, who read your letter with great interest, begged to be remembered to "his old friend." In order to save you the trouble of writing again I shall assume, if I do not hear from you in a few days, that you have no objection to your letter being published.

I may mention that the balls for the Japanese aseismatic arrangements for the towers were made of cast iron, and those for the tables in the light-rooms were of gun-metal.

$$
\text { Yours very truly, }
$$

Professor Piazzi Smyth, \&c., \&c.

\section{A. Stevenson}

\section{Westford House, Droitwich, Fune 13, $188_{5}$}

Dear Mr. D. A. Stevenson,-Yours of the IIth has reached me here ; and, as I left Edinburgh on that day, it was a happy thought of yours to say that, if you did not hear from me soon you would assume my consent to your making some public use of my letter to your worthy father. For, in so far as I wrote it at all, I am ready to stand by it before many or few.

But it was only the beginning of what might have been said and that I trust you will have perceived, and will supply some of the remaining notanda, such as the B.A. man praising up the system for so decidedly relieving the ball-supported build ing from all the sharp, destructive effects of an earthquakeshock, and leaving only a gentle to-and-fro motion on the balls -because this was so admirably illustrated on your father's experimental model at Milton House-by the ease and safety with which the model lighthouse standing on balls in basins was knocked all about the yard by men with sledge-hammers, when they struck only the lower basins, or what they were fixed on as representing solid, yet earthquake-affected, ground; but the moment they struck the base of the lighthouse taken off the basins and balls and planted on the ground, down toppled lantern and lamps with such a fracture, that no more experiments could be made that day.

Then, again, your father had duly allowed that his system would not defend from vertical earthquake-shocks, but he hoped that they would be far more rare at any one place than horizontal shocks spreading all around and far from the places of vertical action; and exactly so says the B.A. man for himself and his imitation balls and basins.

And then he concludes with that he does hope for so much alleviation to human suffering in earthquake regions from the large amount of safety that balls and basin supports for dwellings must give in a gereral way that seismic science will be elevated in the eyes of the people, or something to that effect. To all which of course you can perfectly agree, both in your own and your father's name. I can mention that the turning-point with him as to the practicability of the scheme was when he ascertained by rigid and calm scientific measures that the amount of absolute motion which had done the most mischief in some of the worst Italian earthquakes was not more than three inches, so that it came legitimately within the compass of the means he first suggested, and R.S.S. Arts duly stamped with its approval ten years ago.

Hereabouts is a different earth effect-viz. the High Street, so called, of Droitwich-going down slowly but surely to fill up the vacancies occasioned below by the ceaseless bringing up of salt-rock dissolved in water pumped by numberless steamengines, and furnishing, it is said, half the human family with that one necessary mineral condiment, salt; and so much vapour of it is in the air that mere residence here for a time is said to cure rheumatism and other complaints, even without taking the celebrated brine baths, of ten times the saltness of the ocean itself. Yours very truly,

\section{PIAZZI SMY'TH}

P.S. - The spectroscopic salt line D is preternaturally strong in the air here; "D" might stand for Droitwich.

\section{SCIENTIFIC SERIALS}

Fournal of the Russian Chemical and Physical Society, vol. xvii. fasc. I. - Annual reports of the Society. - On the isomerism of hydrocarbons according to the theory of substitution, by M. Menshutkin (analysed in another column).-On the preparation of hemines, by M. Schalfeyeff.-On its crystalline forms, by A. Lagorion (with plates). - Notes on an apparatus for washing precipitates; on the oxidation of aromatic amines ; on the action of alcohol on diazo compounds. - On the isomerism of solutions, by W. Alexeyeff.-On the same, by D. Konovaloff.-Minutes of proceedings of the physico-chemical section of the Moscow Socicty of amateurs of Natural Sciences.-On the electrolytic figures of Nobili and Gebhard in the magnetic field, by W. Stchegliaeff (with a plate). - On the collision of absolutely rigid bodies, by $\mathrm{N}$. Schiller, being a mathematical inquiry, to show that the invariability of the vis viziz can be establisher by the geometrical determination of the absolute invariability of the systems.-On the dilatation of liquids, by $\mathrm{K}$. Jouk. Researches at the University of Kieff proved that common ether, ethylic alcohol, sulphurous anhydride, diethylamine, and chloric ethyl comply with the formula $v=a+b \log (\tau-t)$.-Polemic between MM. Kraewitsch, Stoletoff, and Petroff.

Vol. xvii., fasc. 2. - Thermal data for hydrocarbon compound o bromide of aluminium, by G. Gustavson. The figures foind by Berthelot, give for the molecule $\mathrm{Al}_{2} \mathrm{Br}_{6}$ a heat of dissolution equal to 170,600 units, M. Gustavson has found, from a series of six determinations, an average of 180,237 (from 179,926 to $\left.180,76_{3}\right)$. When taking $\mathrm{AlBr}_{3} 3\left(\mathrm{C}_{7} \mathrm{H}_{8}\right)$, the number of calorics received was nearly 168 (from 168 , 00I to 168,567 ). On diallyloxalic acid, and on the preparation of oxalic ether, by E. Schatzky.-On the formation of carbonates of strontium, barium, and calcium, by J. Bevad, being an inquiry into the rapidity of reactions. - On the change of colours of coloured surfaces under artificial light, by Th. Petrushevsky. 